\title{
Contribution of nitrogen from agricultural residues of rye to 'Niagara Rosada' grape nutrition
}

\author{
Gustavo Brunetto ${ }^{\mathrm{a}, *}$, Carlos Alberto Ceretta ${ }^{\mathrm{a}}$, George Wellington Bastos de Melo ${ }^{\mathrm{b}}$, \\ João Kaminski ${ }^{a}$, Gustavo Trentin ${ }^{c}$, Eduardo Girotto ${ }^{\mathrm{d}}$, Paulo Ademar Avelar Ferreira ${ }^{\mathrm{a}}$, \\ Alcione Miotto $^{\mathrm{a}}$, Paulo Cesar Ocheuze Trivelin ${ }^{\mathrm{e}}$ \\ a Universidade Federal de Santa Maria, Centro de Ciências Rurais, Programa de Pós-Graduação em Ciência do Solo, Avenida Roraima, 1000, C.P. 221, CEP \\ 97105-900 Santa Maria, RS, Brazil \\ ${ }^{\mathrm{b}}$ Embrapa Uva e Vinho, Rua Livramento 515, C.P. 130, CEP 95700-000 Bento Gonçalves, RS, Brazil

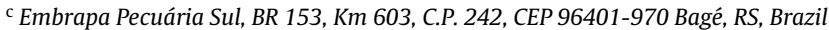 \\ d Instituto Federal de Educação, Ciência e Tecnologia do Rio Grande do Sul, Campus Ibirubá, Rua Nelsi Ribas Fritsch, 1111, CEP 98200-000 Ibirubá, RS, Brazil \\ e Universidade de São Paulo, Centro de Energia Nuclear na Agricultura, CEP 13400-970 Piracicaba, SP, Brazil
}

\section{A R T I C L E I N F O}

\section{Article history:}

Received 7 August 2013

Received in revised form 7 February 2014

Accepted 11 February 2014

Available online 15 March 2014

\section{Keywords:}

Secale cereale

$\mathrm{N}$ uptake

$\mathrm{N}$ distribution

Vitis labrusca

\begin{abstract}
A B S T R A C T
Nitrogen from cover crop residues decomposing on the soil surface may contribute to 'Niagara Rosada' grape nutrition. This study estimated the recovery of $\mathrm{N}$ from the decomposition of rye (Secale cereale) residues deposited on the soil surface in vineyards. Rye litter labeled with ${ }^{15} \mathrm{~N}$ was applied in July 2008 on the soil surface of a 'Niagara Rosada' grape (Vitis labrusca) vineyard in Bento Gonçalves in the southern region of Brazil. In January 2009 and 2010, 'Niagara Rosada' grape plant organs were sampled, and in January 2010 , soil samples were collected in different depths. Total $\mathrm{N}$ and ${ }^{15} \mathrm{~N}$ were analyzed in the plant tissue and soil samples. The $\mathrm{N}$ derived from the rye litter added to the soil surface was mostly accumulated in the annual and perennial organs of the 'Niagara Rosada' grape at a similar percentage. Most of the $\mathrm{N}$ contained in 'Niagara Rosada' grape organs was derived from different $\mathrm{N}$ sources rather than rye litter. Thus, the $\mathrm{N}$ derived from rye litter apparently contributed little to 'Niagara Rosada' grape nutrition in the short time period.
\end{abstract}

(C) 2014 Elsevier B.V. All rights reserved.

\section{Introduction}

Winter cover crop species, including rye (Secale cereale), may be sown and grown between grapevine rows. The purpose of this practice is to reduce weed growth, dissipate the kinetic energy of raindrops, and reduce runoff on the soil surface to increase both water infiltration into the soil profile and nutrient uptake by the grapevines. These nutrients are incorporated into the organic fractions of the plant tissue, which reduces leaching in the soil profile and consequently increases nutrient residence time in the vineyard (King and Berry, 2005; Stevens and Quinton, 2009; Ovalle et al., 2010; Steenwerth and Belina, 2010; Brunetto et al., 2011). The aboveground portions of the cover crop plants may either be cut or desiccated with herbicides, and the residues can then be deposited on the soil surface of the 'Niagara Rosada' grape rows to discourage the growth of plants that may compete with the 'Niagara Rosada'

\footnotetext{
* Corresponding author. Tel.: +55 55 32208157; fax: +55 5532208256 .

E-mail address: brunetto.gustavo@gmail.com (G. Brunetto).
}

grape for water and nutrients (Celette et al., 2009; Brunetto et al. 2011).

Microorganisms use the organic carbon of the cover crop residues that are deposited on the soil surface between the rows of the 'Niagara Rosada' grape plants as a source of energy, which releases $\mathrm{CO}_{2}$ to the atmosphere. Nutrients, including nitrogen, that are contained in the plant tissue residues can be mineralized in the soil, increasing mineral forms, such as nitrate $\left(\mathrm{NO}_{3}{ }^{-}-\mathrm{N}\right)$ and ammonium $\left(\mathrm{NH}_{4}{ }^{+}-\mathrm{N}\right)$, which may be taken up by the grapevines (Ovalle et al., 2010). Mineralized $\mathrm{N}$ derived from the decomposition of residues may be taken up by the 'Niagara Rosada' grape, especially during the vegetative and productive period, and distributed primarily to annual organs, such as leaves, clusters and shoots ( 1 year old), which normally are an $\mathrm{N}$ sink because of the increase of dry matter (Glad et al., 1994; Schreiner and Scagel, 2006). Especially near grape harvest, most of the $\mathrm{N}$ contained in the annual plant organs may be distributed to the perennial organs, such as the cordon, stem, and especially the roots, where it accumulates preferentially in the form of amino acids or proteins, and in the next growth cycle, the $\mathrm{N}$ may once again be redistributed to 
the annual organs (Conradie, 1990, 1991; Bates et al., 2002 Brunetto et al., 2005, 2006a; Menino et al., 2007; Neto et al., 2008). If the decomposition of the residues contributes to grapevine nutrition, as reported in preliminary studies in California (United States of America) (Patrick et al., 2004; King and Berry, 2005), Chile (Ovalle et al., 2010) and the Emilia-Romagna region of Italy (Brunetto et al., 2011), the $\mathrm{N}$ inputs from other sources, such as fertilizers, may be reduced. However, in Brazil, especially in the south, which is the most important wine-growing region of Brazil, the synchronism between the decomposition of cover crop litter and the uptake of the released litter nutrients by 'Niagara Rosada' grape throughout a subsequent growth cycle has not yet been studied. For this type of study, stable isotopes of nitrogen $\left({ }^{15} \mathrm{~N}\right)$ have been used as tracers because they allow precise monitoring of the quantity of $\mathrm{N}$ from fertilizer or even from plant litter that is recovered and compartmentalized in the grapevine (Brunetto et al., 2006a,b, 2011).

The aim of this study was to evaluate the recovery of $\mathrm{N}$ derived from rye residues deposited on the soil surface of vineyards in 'Niagara Rosada' grape plants.

\section{Materials and methods}

\subsection{Labeling procedures}

In April 2008, an untilled Typic Hapludalf soil sample (Soil Survey Staff, 2006) was collected, passed through a sieve, mixed with sand ( $10 \%$ of the total soil volume) and placed in amianthus asbestos boxes in a greenhouse, where rye seeds were sown. Two weeks after emergence of the plants, a urea solution, enriched with 5 at.\% ${ }^{15} \mathrm{~N}$ excess was applied to the amended soil. This application was repeated four times at weekly intervals, providing a total of $10 \mathrm{~g} \mathrm{~N} \mathrm{~m}^{-2}$. The plants were watered daily, and weeds were eliminated weekly to prevent them from taking up ${ }^{15} \mathrm{~N}$. In July 2008 , the stem of the rye plants was severed at ground level, and the above-ground plant parts were weighed for the determination of green weight. A sample was then removed and dried in a laboratory oven with forced-air circulation at $65^{\circ} \mathrm{C}$ until constant weight. The dry matter (DM) was subsequently saved for chemical characterization, and the rest of the green matter was stored in reserve. The rye litter deposited on the soil surface contained $462.0 \mathrm{~g} \mathrm{~kg}^{-1}$ cellulose, $56.0 \mathrm{~g} \mathrm{~kg}^{-1}$ lignin, $349 \mathrm{~g} \mathrm{~kg}^{-1}$ total $\mathrm{C}, 41.0 \mathrm{~g} \mathrm{~kg}^{-1}$ total $\mathrm{N}$, 2.37 at.\% ${ }^{15} \mathrm{~N}$ excess, $2.7 \mathrm{~g} \mathrm{~kg}^{-1}$ total $\mathrm{P}, 8.5 \mathrm{~g} \mathrm{~kg}^{-1}$ total $\mathrm{K}, 1.3 \mathrm{~g} \mathrm{~kg}^{-1}$ total $\mathrm{Ca}$ and $1.1 \mathrm{~g} \mathrm{~kg}^{-1}$ total $\mathrm{Mg}$.

\subsection{Description of the experiment}

The experiment was carried out from July 2008 to January 2010 in an experimental vineyard of Embrapa Uva e Vinho in Bento Gonçalves (Latitude $29^{\circ} 09^{\prime} 44^{\prime \prime} \mathrm{S}$ and Longitude $51^{\circ} 31^{\prime} 50^{\prime \prime} \mathrm{W}$ ) in the State of Rio Grande do Sul in southern Brazil on the 'Niagara Rosada' grape (Vitis labrusca) grafted on Paulsen 1103 rootstock and grown at a density of 3033 plants per hectare using a trellis training system. The 'Niagara Rosada' grapevines were six years old. The climate of the region, according to the Köppen classification, is Cfa subtropical, with the coldest months occurring in June and July, when the mean minimum temperature is $8^{\circ} \mathrm{C}$ and the mean maximum temperature is $17^{\circ} \mathrm{C}$. The hottest months are January and February, with a mean minimum temperature of $17^{\circ} \mathrm{C}$ and a mean maximum temperature of $26^{\circ} \mathrm{C}$. The mean annual rainfall is $1736 \mathrm{~mm}$. The average rainfall, air and soil temperatures, and air humidity data throughout the experimental period are shown in Table 1. The soil was a Typic Hapludalf, with the characteristics described in Table 2. Within a $1.2 \mathrm{~m}$ wide strip centered along the 'Niagara Rosada' grape row, the weeds were desiccated with a nonresidual herbicide, and between the plant rows, a mixture of Lolium perenne, S. cereale and
Table 1

Accumulated rainfall; mean air temperature; mean soil temperature (at the depth of $0.00-0.05 \mathrm{~m}$ ); mean air relative humidity $(\mathrm{RH})$ during the experimental period.

\begin{tabular}{lrlll}
\hline Years-months & $\begin{array}{c}\text { Rainfall } \\
(\mathrm{mm})\end{array}$ & $\begin{array}{l}\text { Air temperature } \\
\left({ }^{\circ} \mathrm{C}\right)\end{array}$ & $\begin{array}{l}\text { Soil temperature } \\
\left({ }^{\circ} \mathrm{C}\right)\end{array}$ & $\begin{array}{l}\text { Air RH } \\
(\%)\end{array}$ \\
\hline $\begin{array}{l}\text { 2009 } \\
\text { July }\end{array}$ & 97.8 & 10.2 & 11.5 & 78 \\
August & 257.9 & 15.2 & 14.8 & 78 \\
September & 411.7 & 14.6 & 15.9 & 84 \\
October & 145.1 & 16.7 & 18.4 & 75 \\
November & 359.5 & 21.6 & 22.8 & 83 \\
December & 232.6 & 21.2 & 24.2 & 80 \\
2010 & & & & 83 \\
January & 296.4 & 22.0 & 24.2 & 79 \\
February & 167.1 & 23.0 & 25.0 & 81 \\
March & 57.2 & 20.7 & 22.9 & 87 \\
April & 142.1 & 17.5 & 19.2 & 81 \\
May & 154.7 & 14.2 & 15.4 & 78 \\
June & 129.9 & 13.1 & 13.8 & 76 \\
July & 213.2 & 12.7 & 13.5 & 80 \\
August & 48.8 & 13.0 & 13.5 & 77 \\
September & 237.9 & 15.5 & 16.6 & 71 \\
October & 48.8 & 15.6 & 18.0 & 74 \\
November & 89.5 & 18.4 & 21.0 & 80 \\
December & 94.3 & 20.9 & 23.7 & \\
2011 & & & 25.2 & \\
January & 174.6 & 22.9 & & \\
\hline
\end{tabular}

Paspalum notatum was grown. During the experiment the 'Niagara Rosada' grape received no applications of mineral $\mathrm{N}$ fertilizers. On July $1,2008,1038 \mathrm{~g}$ of rye green manure, the equivalent of $192.74 \mathrm{~g}$ of DM, was applied on an area of $0.96 \mathrm{~m}^{2}(0.80 \mathrm{~m} \times 1.20 \mathrm{~m})$ on the soil surface around each grapevine plant. The amount of added DM corresponded to $2.0 \mathrm{Mg} \mathrm{ha}^{-1}$, containing $41.0 \mathrm{~g} \mathrm{~kg}^{-1} \mathrm{~N}$, which is equivalent to $82 \mathrm{~kg}$ of $\mathrm{N} \mathrm{ha}^{-1}$ (labeled with 2.37 at.\% ${ }^{15} \mathrm{~N}$ excess). A nylon screen with a $5 \mathrm{~mm}$ aperture mesh was placed on the rye biomass to avoid possible losses caused by wind and animals. A completely randomized experimental design with five replications was used, and five other grapevines that received rye biomass without added ${ }^{15} \mathrm{~N}$ served as controls.

In January 2009, at 28 weeks after depositing the rye biomass on the soil surface, eight clusters of grapes were collected at random from each 'Niagara Rosada' grape. An established number of berries from the top, middle and lower part of each cluster were collected, frozen in liquid $\mathrm{N}$, dried in a lyophilizer until reaching a constant weight and then adequately stored. The eight rachises were reserved. Three shoots ( 1 year old) and a fraction of a cordon with a length of $0.03 \mathrm{~m}$ were then collected at random from each 'Niagara Rosada' grape and reserved. Soon afterwards, the leaves from each new shoot were collected and reserved. The leaves, the shoots and the rachises were dried at $65^{\circ} \mathrm{C}$ until they reached a constant weight, ground and stored.

Table 2

Main physical and chemical characteristics of the soil in the experimental site at the depth of $0.00-0.20 \mathrm{~m}$.

\begin{tabular}{llc}
\hline Attribute & Unit & $0.00-0.20 \mathrm{~m}$ \\
\hline Clay & $\mathrm{g} \mathrm{kg}^{-1}$ & 162 \\
Silt & $\mathrm{g} \mathrm{kg}^{-1}$ & 558 \\
Sand & $\mathrm{g} \mathrm{kg}^{-1}$ & 280 \\
Organic matter & $\mathrm{g} \mathrm{kg}^{-1}$ & 218 \\
Organic C & $\mathrm{g} \mathrm{kg}^{-1}$ & 126 \\
pH in $\mathrm{H}_{2} \mathrm{O}$ & - & 6.00 \\
Total N & $\mathrm{mg} \mathrm{kg}^{-1}$ & 2.500 \\
Mineral N & $\mathrm{mg} \mathrm{kg}^{-1}$ & 20 \\
Aluminum (exchangeable) & $\mathrm{mg} \mathrm{kg}^{-1}$ & 0.00 \\
Magnesium (exchangeable) & $\mathrm{mg} \mathrm{kg}^{-1}$ & 413 \\
Calcium (exchangeable) & $\mathrm{mg} \mathrm{kg}^{-1}$ & 1593 \\
Phosphorus (availability) & $\mathrm{mg} \mathrm{kg}^{-1}$ & 33 \\
Potassium (exchangeable) & $\mathrm{mg} \mathrm{kg}^{-1}$ & 246 \\
\hline
\end{tabular}


In January 2010, at 72 weeks after applying the rye biomass on the soil surface, the grapevines were collected and separated into clusters (berries plus rachis), leaves, stems, cordons and shoots (1 year old). The clusters were then weighed, and the berries at the top, middle and lower part of each cluster were collected. Berries were immediately frozen in liquid $\mathrm{N}$, dried in a lyophilizer to a constant weight and reserved. The remaining berries were removed from the clusters, and the rachises were reserved. The leaves, stems, cordons, shoots and rachises of each 'Niagara Rosada' grape were dried at $65^{\circ} \mathrm{C}$, ground and reserved.

In the $0.96 \mathrm{~m}^{2}$ at each grapevine, a trench was opened, and soil was collected at the depths of 0.0-0.05, 0.05-0.10, 0.10-0.15, and $0.15-0.20 \mathrm{~m}$. The soil was air dried, ground and stored.

\subsection{Plant tissue and soil analysis}

The total $\mathrm{N}$ and the ${ }^{15} \mathrm{~N}$ excess in the rye biomass, the 'Niagara Rosada' grape organs and the soil samples were determined in a mass spectrometer (Hydra 20/20 model, PDZ Europa, Crewe, UK) coupled to an automatic $C$ and $N$ analyzer (ANCA GSL model, Sercon Co., Krewe, UK). The total C, P, K, Ca and Mg in the rye biomass were determined according to Tedesco et al. (1995). The cellulose and lignin contents of the biomass were determined according to Blaschke et al. (2002).

The fraction of the soil $\mathrm{N}$ derived from the labeled litter was calculated using the following equation:

$\mathrm{N}_{\text {litter } \rightarrow \text { soil }}=$ total $\mathrm{N}$ content $\mathrm{soil}_{\text {sil }} \times \frac{{ }^{15} \mathrm{~N}_{\text {soil }}-{ }^{15} \mathrm{~N}_{\text {control }}}{{ }^{15} \mathrm{~N}_{\text {litter }}-{ }^{15} \mathrm{~N}_{\text {natural }}}$

while the fraction of the $\mathrm{N}$ derived from the labeled litter that was recovered in the 'Niagara Rosada' grape organs was calculated as follows:

$\mathrm{N}_{\text {litter } \rightarrow \text { vine }}=$ total $\mathrm{N}$ content vine organ $_{\text {. }}$

$$
\times \frac{{ }^{15} N_{\text {vine organ }}-{ }^{15} N_{\text {control vine organ }}}{{ }^{15} N_{\text {litter }}-{ }^{15} N_{\text {natural }}}
$$

where ${ }^{15} \mathrm{~N}_{\text {natural }}$ is 0.3663 at.\% ${ }^{15} \mathrm{~N}$.

\subsection{Statistical treatment of the data}

The data were subjected to analysis of variance, and when this analysis indicated statistically significant treatment effects, the data were subjected to the Scott-Knott mean comparison test $(p<0.05)$.

\section{Results and discussion}

\subsection{N distribution in the 'Niagara Rosada' grape}

Twenty-eight weeks after depositing the rye litter on the surface of the soil, the total $\mathrm{N}$ concentration was greater in the 'Niagara Rosada' grape leaves than in the cordon, the shoots ( 1 year old) and the berries plus rachises (Table 3 ). Nevertheless, the total $\mathrm{N}$ concentration in the cordon and shoots was greater than that observed in the berries plus rachises. In contrast, the atom $\%{ }^{15} \mathrm{~N}$ excess did not differ significantly among the grapevine organs, which was reflected in the $\mathrm{N}$ concentration derived from the litter; thus, the $\mathrm{N}$ from the litter was redistributed among all of the plant organs (Table 3).

Seventy-two weeks after the deposition of the rye litter on the soil surface, the stems, cordon, and shoots yielded more DM than the leaves and rachises (Table 3 ). The greatest concentration of total $N$ was verified in the 'Niagara Rosada' grape leaves, which confirmed the results obtained at 28 weeks after the deposition of the rye litter on the soil surface. The total $\mathrm{N}$ concentration of the rachises was less than that of the leaves but greater than that of the shoots, which showed did not differ significantly total $\mathrm{N}$ concentration that exceeded those in the cordon and stem. The leaves also contained a greater quantity of total $\mathrm{N}\left(\mathrm{mg} \mathrm{vine}^{-1}\right)$ than were found in the other organs. However, the cordon and shoots showed a concentration of total $\mathrm{N}$ lower than the leaves but greater than the stems and the rachises. The atom $\%{ }^{15} \mathrm{~N}$ excess did not differ significantly among the 'Niagara Rosada' grape organs, which was reflected in the concentration and amount of $\mathrm{N}$ derived from the litter $\left(\mathrm{mg} \mathrm{vine}^{-1}\right)$.

The greater concentrations or quantities of total $\mathrm{N}$, as well as the trend for a greater atom $\%{ }^{15} \mathrm{~N}$ excess in the 'Niagara Rosada' grape leaves than in the other organs (e.g., shoots and cordon) at 28 and 72 weeks after the deposition of the rye litter on the soil surface (Table 3), may be attributed to the rapid cell division of the leaves, which is reflected in their increased DM (Conradie, 1990; Brunetto et al., 2006a,b). Therefore, the leaves and also the grape clusters (berries plus rachis) (Table 3 ) act as an $\mathrm{N}$ sink during the vegetative and productive cycles of the 'Niagara Rosada' grape up until grape ripening (Kliewer and Cook, 1971, 1974; Williams, 1987; Glad et al., 1994; Schreiner and Scagel, 2006). The N derived from the litter was accumulated in greater concentrations in the different 'Niagara Rosada' grape organs at 28 weeks than at 72 weeks after the residue addition, due to the dilution effect at the latter stage (Table 3). However, both evaluations demonstrated that the concentration of $\mathrm{N}$ derived from the litter was less than $2 \%$ for all the 'Niagara Rosada' grape organs, indicating that more than $98 \%$ of the $\mathrm{N}$ contained in the tested organs was derived from $\mathrm{N}$ sources other

Table 3

Dry matter, total N, ${ }^{15} \mathrm{~N}$ excess and $\mathrm{N}$ derived from litter in 'Niagara Rosada' grape organs at 28 and 72 weeks after deposition of rye litter.

\begin{tabular}{|c|c|c|c|c|c|c|}
\hline \multirow[t]{2}{*}{ Organ } & \multirow{2}{*}{$\begin{array}{l}\text { Dry matter } \\
\left(\mathrm{g} \mathrm{vine}^{-1}\right)\end{array}$} & \multicolumn{2}{|l|}{ Total N } & \multirow{2}{*}{$\begin{array}{l}{ }^{15} \mathrm{~N} \\
\text { (at.\% }{ }^{15} \mathrm{~N}, \text { excess) }\end{array}$} & \multicolumn{2}{|l|}{$\mathrm{N}$ derived from litter } \\
\hline & & ( kg $^{-1}$ dry matter $)$ & $\left(\right.$ mg vine $\left.^{-1}\right)$ & & (\% of total $\mathrm{N}$ in the organ) & $\left(\right.$ mg vine $\left.^{-1}\right)$ \\
\hline & \multicolumn{6}{|c|}{28 weeks after deposition of the residues on the soil surface } \\
\hline Leaves & - & $36.7 a^{* *}$ & - & $0.0432 \mathrm{a}$ & $1.84 \mathrm{a}$ & - \\
\hline Cordon & - & $13.4 \mathrm{~b}$ & - & $0.0407 \mathrm{a}$ & $1.73 \mathrm{a}$ & - \\
\hline Shoots ( 1 year old) & - & $12.5 \mathrm{~b}$ & - & $0.0293 \mathrm{a}$ & $1.24 \mathrm{a}$ & - \\
\hline \multirow[t]{2}{*}{ Berries + Rachis } & - & $10.0 \mathrm{c}$ & - & $0.0340 \mathrm{a}$ & $1.45 \mathrm{a}$ & - \\
\hline & \multicolumn{6}{|c|}{72 weeks after deposition of the residues on the soil surface } \\
\hline Leaves & $71.97 \mathrm{~b}$ & $23.8 \mathrm{a}$ & $1709.02 \mathrm{a}$ & $0.0120 \mathrm{a}$ & $0.50 \mathrm{a}$ & $8.69 \mathrm{a}$ \\
\hline Stem & $163.16 \mathrm{a}$ & $3.3 \mathrm{e}$ & $518.50 \mathrm{c}$ & $0.0160 \mathrm{a}$ & $0.68 \mathrm{a}$ & $3.64 \mathrm{a}$ \\
\hline Cordon & $187.88 \mathrm{a}$ & $4.7 \mathrm{~d}$ & $874.61 \mathrm{~b}$ & $0.0166 \mathrm{a}$ & $0.71 \mathrm{a}$ & $6.67 \mathrm{a}$ \\
\hline Shoots ( 1 year old) & $128.32 \mathrm{a}$ & $6.6 \mathrm{c}$ & $838.39 \mathrm{~b}$ & $0.0120 \mathrm{a}$ & $0.54 \mathrm{a}$ & $4.56 \mathrm{a}$ \\
\hline Rachis & $1.13 \mathrm{~b}$ & $17.9 \mathrm{~b}$ & $20.21 \mathrm{~d}$ & $0.0100 \mathrm{a}$ & $0.44 \mathrm{a}$ & $0.10 \mathrm{a}$ \\
\hline Berries ${ }^{*}$ & 149.79 & 7.4 & 1105.16 & 0.0100 & 0.54 & 5.96 \\
\hline
\end{tabular}

* Fresh matter of the berries. For that reason, the parameters of berries at 72 weeks after deposition of the residues on the soil surface were not compared to the parameters of the other plant organs.

Mean values with different letters in the same column differ significantly (Scott-Knott test, $p<0.05$ ). 
Table 4

Total $\mathrm{N}$ concentration, ${ }^{15} \mathrm{~N}$ excess and $\mathrm{N}$ derived from litter at soil depths under rye in decomposition.

\begin{tabular}{llll}
\hline Depth $(\mathrm{m})$ & Total N $(\%)$ & ${ }^{15} \mathrm{~N}($ at.\% excess) & N derived from litter $(\%)$ \\
\hline $0.00-0.05$ & $1.4 \mathrm{a}^{*}$ & $0.0100 \mathrm{a}$ & $0.41 \mathrm{a}$ \\
$0.05-0.10$ & $0.8 \mathrm{~b}$ & $0.0023 \mathrm{~b}$ & $0.09 \mathrm{~b}$ \\
$0.10-0.15$ & $0.8 \mathrm{~b}$ & $0.0020 \mathrm{~b}$ & $0.07 \mathrm{~b}$ \\
$0.15-0.20$ & $0.8 \mathrm{~b}$ & $0.0020 \mathrm{~b}$ & $0.08 \mathrm{~b}$
\end{tabular}

* Mean values with different letters in the same column differ significantly (Scott-Knott test, $p<0.05$ ).

than the litter. The low percentage of litter-derived $\mathrm{N}$ in the "Niagara Rosada' grape may be attributed to a number of possible causes. (i) One is the volatilization of $\mathrm{NH}_{3}-\mathrm{N}$ during the decomposition of rye residues on the soil surface, as well as volatilization from the grape leaves throughout the vegetative and productive period, which is common and relevant in fruit-bearing species that have a large leaf area (Kumagail et al., 2011). (ii) Another is the loss of the mineral $\mathrm{N}$ forms by runoff from the soil surface and by leaching into the soil profile, especially the $\mathrm{NO}_{3}{ }^{-}-\mathrm{N}$ form. $\mathrm{NO}_{3}{ }^{-}-\mathrm{N}$ is especially susceptible to loss from these processes because it forms outer-sphere complexes with the functional groups on the surface of soil particles. Thus, $\mathrm{NO}_{3}{ }^{-}-\mathrm{N}$ easily accompanies the descent of water into the soil profile (Lorensini et al., 2012). However, we believe that the quantity of $\mathrm{N}$ transferred through leaching was greater than through runoff in the present study because the percentages of $\mathrm{N}$ derived from the litter were small at depths up to $0.20 \mathrm{~m}$ (Table 4). (iii) The $\mathrm{N}_{2} \mathrm{O}-\mathrm{N}$ denitrification in soil micropores saturated with water in the residue application location is another plausible reason for the low percentage of litter-derived $\mathrm{N}$ in the 'Niagara Rosada' grape (King and Berry, 2005). (iv) Fewer young, white roots, which are responsible for more $\mathrm{N}$ uptake than old, dark roots, may also have developed in the area that received the deposition of rye litter (Eissenstat, 2007); (v) in addition, low percentage of litter-derived $\mathrm{N}$ may be attributed to low mineralization of soil organic matter, which may have complexed part of the ${ }^{15} \mathrm{~N}$ applied. Moreover, there may be availability of $\mathrm{N}$ in the soil derived from other sources (unlabeled), such as plant residues (e.g., senescent leaves, pruned stems and even residues from other cover crop species deposited between the crop rows) (Scandellari et al., 2007; Neto et al., 2009; Ventura et al., 2010; Brunetto et al., 2011). (vi) The ability of soil microorganisms in competition with plants for $\mathrm{N}$ uptake is another factor that may have limited plant $\mathrm{N}$ uptake from the litter (Tagliavini et al., 2007; Tonon et al., 2007). Still other possible causes are (vii) the potential presence of strong physical adsorption of soil mineral $\mathrm{N}\left(\mathrm{NH}_{4}-\mathrm{N}\right)$ (Brunetto et al., 2011), (viii) the accumulation of $\mathrm{N}$ in the roots, factors which were not evaluated in this study (Hanson and Howell, 1995; Patrick et al., 2004). (ix) Finally, it is possible that the $\mathrm{N}$ available from the rye litter was greater in the soil and was lost before the nutrient uptake by the 'Niagara Rosada' grape reached its peak, which coincides with budbreak of the plants (Conradie, 1991; Löhnertz, 1991; Glad et al., 1994; Araujo et al., 1995). Budbreak is a phenological stage in which the air and soil temperatures are mild and the soil moisture is adequate because of frequent rainfall, which, in addition to other factors, maintains and/or increases soil microbial biomass activity, nutrient availability and root activity (Volder et al., 2005; Eissenstat, 2007). In the present study, budbreak occurred in the last week of August, nearly 60 days after the deposition of the rye residues on the soil surface. According to some studies, such as those of Brunetto et al. (2011) and their collaborators, in grass residues such as those of $L$. perenne deposited in vineyards, more than $70 \%$ of the litter-derived $\mathrm{N}$ is released to the soil within 8 weeks of the deposition of the biomass on the soil surface. Tagliavini et al. (2007) also report that L. perenne residues deposited on orchard soils release more than $40 \%$ of their $N$ within 7 weeks of deposition. Moreover, in addition to cover crop residues in decomposition on the soil surface, Neto et al. (2009) report that decomposition of senescent leaves from the pear tree also contributed to plant nutrition.

Recovery of litter-derived N similar to that obtained from 'Niagara Rosada' grape leaves in the present study was reported by Brunetto et al. (2011) in Chardonnay grapevines that were grown in Italy and treated with L. perenne and Trifolium repens biomass. According to these authors, the plant leaves derived less than 1\% of their $\mathrm{N}$ from the litter when tested 8 weeks after deposition of the two cover plant residues on the soil surface. The litter-derived $\mathrm{N}$ recoveries were also low for other parts of the grape plant sampled by Brunetto et al. (2011) at 16 weeks after deposition of the $L$. perenne and $T$. repens residues, with $0.71 \%$ recovery in the berries, $0.51 \%$ in the rachises, $0.58 \%$ in the leaves, $0.61 \%$ in the shoots $(1$ year old) and $0.21 \%$ in the cordons. These percentages are similar to those obtained in the present study (Table 3 ). In addition, Patrick et al. (2004) reported that in Chardonnay grapevines grown with a mixture of ${ }^{15} \mathrm{~N}$-labeled cover crop species (Vicia sativa, Vicia sativa villosa, Vicia faba, Avena sativa and Pisum sativum), which provided $81 \mathrm{~kg}$ of $\mathrm{N} \mathrm{ha}^{-1}$ to the soil, a quantity similar to that added in the present study, nearly $0.28 \%$ of the litter-derived $\mathrm{N}$ was recovered in the grapevine leaves at 20 weeks after deposition of the residues on the soil surface. This percentage was lower than that observed in the present study.

\section{2. $N$ distribution in the soil}

The greatest total $\mathrm{N}$ concentration and atom $\%{ }^{15} \mathrm{~N}$ excess were observed in the uppermost soil layer $(0.00-0.05 \mathrm{~m})$ examined (Table 4). These results reflected the greater concentration of litter-derived $\mathrm{N}$ in this uppermost soil layers and was residual. The accumulation of total $\mathrm{N}$ and litter-derived $\mathrm{N}$ concentration did not differ significantly in the $0.05-0.10,0.10-0.15$ and $0.15-0.20 \mathrm{~m}$ layers.

The accumulation of not only the total $\mathrm{N}$ but also the litterderived $\mathrm{N}$ in the uppermost soil layer most likely occurred because the rye litter was deposited on the soil surface without incorporation, where its $\mathrm{N}\left({ }^{15} \mathrm{~N}\right)$ was released after microbial decomposition of the litter. After being released and dissolved in the soil, the ${ }^{15} \mathrm{~N}$ can replace part of the unlabeled inorganic soil $\mathrm{N}$ adsorbed to colloids or immobilized within the microbial biomass (Jenkinson et al., 1985) and may later become available in the soil throughout the vegetative and productive cycles of the grapevine (Brunetto et al., 2006a). The percentage of atom $\%{ }^{15} \mathrm{~N}$ excess, which was reflected in the $\mathrm{N}$ derived from litter, was not significant in the soil layers from $0.05-0.10$ to $0.15-0.20 \mathrm{~m}$ (Table 4 ), indicating that there was little transfer of $\mathrm{N}$ by leaching, which is reasonable because the soil has a clayey texture (Table 2). Thus, part of the $\mathrm{N}$ applied in the rye residues was most likely transferred by other processes, such as runoff, volatilization and denitrification (Lorensini et al., 2012). The litter-derived $\mathrm{N}$ located in the soil profile may be recovered by the 'Niagara Rosada' grape during subsequent growth cycles because 'Niagara Rosada' has roots that extend up to a depth of $0.6 \mathrm{~m}$, according to Brunetto et al. (2006b). Similar results were obtained by Brunetto et al. (2011), who reported percentages of $\mathrm{N}$ derived from the litter of $L$. perenne and T. repens in vineyard soils of nearly 0.30 and $0.08 \%$ up to depths of 0.30 and $0.60 \mathrm{~m}$, respectively. The amount of litter-derived $\mathrm{N}$ recovered in the $0.00-0.20 \mathrm{~m}$ soil layer and in the grapevine was only 0.37 and $0.07 \mathrm{~kg} \mathrm{ha}^{-1}$, respectively; thus, the total quantity of litter-derived $\mathrm{N}$ in the grapevine plus the soil $(0.00-0.20 \mathrm{~m})$ was $0.44 \mathrm{~kg} \mathrm{ha}^{-1}$.

\section{Conclusions}

The $\mathrm{N}$ derived from the rye litter added to the soil surface was mostly accumulated in the annual and perennial organs of the 
'Niagara Rosada' grape at a similar percentage. Most N contained in Niagara Rosada' grape organs was derived from $\mathrm{N}$ sources other than rye litter. Thus, the $\mathrm{N}$ derived from rye litter apparently contributed little to 'Niagara Rosada' grape nutrition in the short time period.

\section{Acknowledgements}

We are grateful to the CAPES (Edital 034/2007) for scholarships and other financial resources. The first, second, fourth and ninth authors thank the CNPq for research grants.

\section{References}

Araujo, F., Williams, L.E., Matthews, M.A.A., 1995. Comparative study of young "Thompson Seedless" grapevines (Vitis vinifera L.) under drip and furrow irrigation. II. Growth, water use efficiency and nitrogen partitioning. Sci. Hortic. 60, 251-265.

Bates, T.R., Dunst, R.M., Joy, P., 2002. Seasonal dry matter, starch, and nutrient distribution in 'Concord' grapevine roots. HortScience 37, 313-316.

Blaschke, L., Forstreuter, M., Sheppard, L.J., Leith, I.K., Murray, M.B., Polle, A., 2002. Lignification in beech (Fagus sylvatica) grown at elevated $\mathrm{CO}_{2}$ concentrations: interactions with nutrient availability and leaf maturation. Tree Physiol. 22, 469-477.

Brunetto, G., Kaminski, J., Melo, G.W.B., Gatiboni, L.C., Urquiaga, S., 2005. Absorção e redistribuição do nitrogênio aplicado via foliar em videiras jovens. Rev. Bras. Frutic. 27, 110-114.

Brunetto, G., Kaminski, J., Melo, G.W.B., Rheinheimer, D.S., 2006a. Recuperação e distribuição do nitrogênio fornecido a videiras jovens. Pesq. Agropec. Bras. 41, 1299-1304.

Brunetto, G., Kaminski, J., Melo, G.W.B., Bruning, F.S., Mallmann, F.J.K., 2006b. Destino do nitrogênio em videiras "Chardonnay" e "Riesling Renano" quando aplicado no inchamento das gemas. Rev. Bras. de Frutic. 28, 497-500.

Brunetto, G., Ventura, M., Scandellari, F., Ceretta, C.A., Kaminski, J., Melo, G.W.B., Tagliavini, M., 2011. Nutrients release during the decomposition of mowed perennial ryegrass and white clover and its contribution to nitrogen nutrition of grapevine. Nutr. Cycl. Agroecosyst. 90, 299-308.

Celette, F., Findeling, A., Gary, C., 2009. Competition for nitrogen in an unfertilized intercropping system: the case of an association of grapevine and grass cover in a Mediterranean climate. Eur. J. Agron. 30, 41-51.

Conradie, W.J., 1990. Distribution and translocation of nitrogen absorbed during late spring by two-year-old grapevines grown in sand culture. Am. J. Enol. Vitic. 41, 241-250.

Conradie, W.J., 1991. Distribution and translocation of nitrogen absorbed during early summer by two-year-old grapevines grown in sand culture. Am. J. Enol. Vitic. 42, 180-190.

Eissenstat, D.M., 2007. Dinamica di crescita delle radici nelle colture da frutto. Italus Hortus 14, 1-8.

Glad, C., Farineau, J., Regnard, J.L., Morot-Gaudry, J.L., 1994. The relative contribution of nitrogen originating from two seasonal $15 \mathrm{~N}$ supplies to the total nitrogen pool present in the bleeding sap and in whole Vitis vinifera cv Pinot noir grapevines at bloom time. Am. J. Enol. Vitic. 45, 327-332.

Hanson, E.J., Howell, G.S., 1995. Nitrogen accumulation and fertilizer use efficiency by grapevines in short-season growing areas. HortScience 30, 504-507.

Jenkinson, D.S., Fox, R.H., Rayner, J.H., 1985. Interactions between fertilizer nitrogen and soil nitrogen - the so-called "priming" effect. J. Soil. Sci. 36, 425-444.
King, A.P., Berry, A.M., 2005. Vineyard ${ }^{15} \mathrm{~N}$, nitrogen and water status in perennia clover and bunch grass cover crop systems of California's central valley. Agric. Ecosyst. Environ. 109, 262-272.

Kliewer, W.M., Cook, J.A., 1971. Arginine and total free amino acids as indicators of the nitrogen status of grapevines. J. Am. Soc. Hortic. Sci. 96, 581-587.

Kliewer, W.M., Cook, J.A., 1974. Arginine levels in grape canes and fruits as indicators of nitrogen status of vineyards. Am. J. Enol. Vitic. 25, 111-117.

Kumagail, E., Araki, T., Hamaoka, N., Ueno, O., 2011. Ammonia emission from rice leaves in relation to photorespiration and genotypic differences in glutamine synthetase activity. Ann. Bot. 108, 1381-1386.

Löhnertz, O., 1991. Soil nitrogen and the uptake of nitrogen in grapevines. In: International Symposium on Nitrogen in Grapes and Wine, Washington. Proceeding ... Washington, The American Society for Enology and Viticulture, pp. 1-11.

Lorensini, F., Ceretta, C.A., Girotto, E., Cerini, J.B., Lourenzi, C.R., De Conti, L., Trindade, M.M., Melo, G.W.B., Brunetto, G., 2012. Lixiviação e volatilização de nitrogênio em um Argissolo cultivado com videira submetida à adubação nitrogenada. Ciência Rural 42, 1173-1179.

Menino, M.R., Carranca, C., De Varennes, A., 2007. Distribution and remobilization of nitrogen in young non-bearing orange trees grown under Mediterranean conditions. J. Plant Nutr. 30, 1083-1096.

Neto, C., Carranca, C., Clemente, J., De Varennes, A., 2008. Nitrogen distribution, remobilization and re-cycling in young non-bearing 'Rocha' pear trees. Sci. Hortic. 118, 299-307.

Neto, C., Carranca, C., Clemente, J., 2009. Senescent leaf decomposition in a Mediterranean pear orchard. Eur. J. Agron. 30, 34-40.

Ovalle, C.S., Arredondo, A., Del Pozo, F., Fernández, J., Chavarría, A., 2010. Arrowlea clover (Trifolium vesiculosum Savi): a new species of annual legumes for high rainfall areas of the Mediterranean climate zone of Chile. Chil. J. Agric. Res. 70 170-177.

Patrick, A.E., Smith, R., Keck, K., Berry, A.M., 2004. Grapevine uptake of 15N labeled nitrogen derived from a winter-annual leguminous cover-crop mix. Am. J. Enol Vitic. 55, 187-190.

Scandellari, F., Tonon, G., Thalheimer, M., Ceccon, C., Gioacchini, P., Aber, J.D., Tagliavini, M., 2007. Assessing nitrogen fluxes from roots to soil associated to rhizodeposition by apple (Malus domestica) trees. Trees-Struct. Funct. 21, 499-505.

Schreiner, R.P., Scagel, C.F., 2006. Nutrient uptake and distribution in a mature 'Pinot Noir' vineyard. HortScience 41, 336-345.

Soil Survey Staff, 2006. Soil Taxonomy: A Basic System of Soil Classification for Making and Interpreting Soil Surveys, 2nd ed. US Government Printing Office Washington, DC, pp. 333p.

Steenwerth, K.L., Belina, K.M., 2010. Vineyard weed management practices influence nitrate leaching and nitrous oxide emissions. Agric. Ecosyst. Environ. 138, 127-131.

Stevens, C.J., Quinton, J.N., 2009. Policy implications of pollution swapping. Phys. Chem. Earth 34, 589-594.

Tagliavini, M., Tonon, G., Scandellari, F., Quiñones, A., Palmieri, S., Menarbin, G., Gioacchini, P., Masia, A., 2007. Nutrient recycling during the decomposition of apple leaves (Malus domestica) and mowed grasses in an orchard. Agric. Ecosyst. Environ. 118, 191-200.

Tedesco, M.J., Gianello, C., Bissani, C.A., Bohnen, H., Volkweiss, S.J., 1995. Análise do solo, planta e outros materiais. UFRGS, Porto Alegre.

Tonon, G., Ciavatta, C., Solimando, D., Gioacchini, P., Tagliavini, M., 2007. Fate of the $15 \mathrm{~N}$ deriving from soil decomposition of abscised leaves and pruning wood from apple (Malus domestica) trees. Soil Sci. Plant Nutr. 53, 79-86.

Ventura, M., Scandellari, F., Bonora, E., Tagliavini, M., 2010. Nutrient release during decomposition of leaf litter in a peach (Prunus pérsica L.) orchard. Nutr. Cycl. Agroecosyst. 87, 115-125.

Volder, A., Smart, D.R., Bloom, A.J., Eissenstat, D.M., 2005. Rapid decline in nitrate uptake and respiration with age in fine lateral roots of grape: implications for root efficiency and competitive effectiveness. New Phytol. 165, 493-502.

Williams, L.E., 1987. Growth of "Thompson Seedless" grapevines: II. Nitrogen distribution. J. Am. Soc. Hortic. 112, 330-333. 